\title{
Petrology, Geochemistry, and Geodynamic Implications of Basaltic Dyke Swarms from the Southern Continental Part of the Cameroon Volcanic Line, Central Africa
}

\author{
Jean Pierre Tchouankoue, Nicole Armelle Simeni Wambo, Armand Kagou Dongmo and \\ Gerhard Wörner
}

Abt. Geochemie, GZG, University Goettingen, Germany

\begin{abstract}
Basaltic dyke swarms in the southern continental part of the Cameroon Volcanic Line (Bangangte, Dschang, Manjo areas) are tholeiitic in composition with 46 to $50 \mathrm{wt} \% \mathrm{SiO}_{2}$ and have moderate $\mathrm{Mg}$-numbers (53-59), medium $\mathrm{TiO}_{2}$ contents (1.48-2,05 wt.\%), and flat to mildly enriched incompatible trace element patterns. Comparison with trace element patterns of representative Cenozoic basaltic rocks of the Cameroon Volcanic Line (Bana anorogenic complex, Mt. Bambouto, Adamawa Plateau basalts) indicates that these dykes are less enriched in light REE and show different incompatible trace element ratios ( $\mathrm{La} / \mathrm{Yb}: 5.7$ to $8.6 ; \mathrm{Zr} / \mathrm{Nb}$ : 7.6 to $12.0 ; \mathrm{Ba} / \mathrm{Th}: 87.7$ to 93.3$)$. The trace element patterns of the dykes and their Sr- and Nd- isotope compositions, however, are similar to those of the pre-Cenozoic volcanic rocks of the Benue Trough in Nigeria. Our data therefore suggest that these dykes represent the magmatic history related to the break-up of Africa and South America and are unrelated to the Tertiary volcanism of the Cameroon Line.
\end{abstract}

Keywords: Basalt dykes, Tholeiites, Phanerozoic, Cameroon volcanic line, West Gondwana.

\section{INTRODUCTION}

Mafic magmatic dykes are important in the characterization and the reconstruction of the tectonomagmatic history of a region. Basalt dykes of the continental part of the Gulf of Guinea in Central Africa are abundant and - if they can be safely differentiated from dikes related to the Cameroon Volcanic Line (CVL)- may be good candidates for a better understanding of the break-up of the Pangea supercontinent during the Mesozoic.

In the present work, we report mineral chemistry, whole rock geochemistry, and $\mathrm{Sr}$ - and $\mathrm{Nd}$-isotopes for 12 basaltic dykes that cut the Precambrian rock assemblages outcropping below the Tertiary volcanic cover of the Cameroon Volcanic Line (CVL) in the areas of Bangangté, Dschang and Manjo (Fig. 1). We compare the trace element patterns of these basalt dykes with the CVL plateau basalts from the Bangangte area (this work), basalts from the Cenozoic Bana anorogenic complex [1], Mt. Bambouto and Ngaounderé plateau basalts [2], as well as basalts from the Benue Through in Nigeria [3].

[4] and [5] on their reconnaissance 1/500000 map of Cameroon recognized the existence of dykes of basaltic affinity within the corridor of the Cameroon Volcanic Line. Poorly constrained K/Ar ages $(417 \pm 8.1 \mathrm{Ma} ; 214 \pm 6.6$ and 148. \pm 3.8 Ma respectively, for two such mafic dykes in the Bangangte area [6] indicate that these basalts could be related to the opening of the South Atlantic Ocean and less likely to initial stages of the building up of the Cameroon

*Address correspondence to this author at the Abt. Geochemie, GZG, University Goettingen, Germany; Tel: 0049551 393971; Fax: 0049551 393982; E-mail: Gwoerne@gwdg.de
Line. These K-Ar ages added to the interest in these basaltic dykes in the perspective of the geodynamic history of the opening of Central Atlantic.

We will use our new geochemical and isotopic data on mafic basement-cutting dikes in south-central Cameroon to (1) better differentiate between products Lower Tertiary CVL magmatism and older dykes that formed within the context of Phanerozoic magmatism linked to the opening of the South Atlantic Ocean, and (2) characterise the magmatism during the opening of the Central Atlantic.

\section{GEOLOGICAL SETTING}

The Precambrian domain of southwestern Cameroon is a part of the Pan-African belt of Central Africa north of the Congo Craton which was formed following the convergence and collision between the Congo-São Francisco cratons, the West African craton and a Pan-African mobile belt ([7-10]).

The tectono-magmatic history of the domain includes a Panafrican massive granitization event $[15,16]$, the opening of the Central Atlantic during the Mesozoic, and the formation of the Cameroon Volcanic Line during the Tertiary. Basaltic dykes are found cutting across the Precambrian basement that is mainly formed by syn-to latetectonic granitoids intruded into a gneissic basement [1014]. Granitoids appear as sheets elongated aggregately to the $\mathrm{N} 30-40^{\circ} \mathrm{E}$ direction. Plutons are parallel to the regional schistosity with planar structures of mean attitude N45$70^{\circ} \mathrm{SE}$. Petrographically, granitoids are fine- to coarsegrained types (granites, granodiorites, monzogranites, granites, syenites) and intrusive massifs are frequently formed by more than one rock type. Amphiboles and biotite form the dominant mafic minerals and muscovite, monazite 


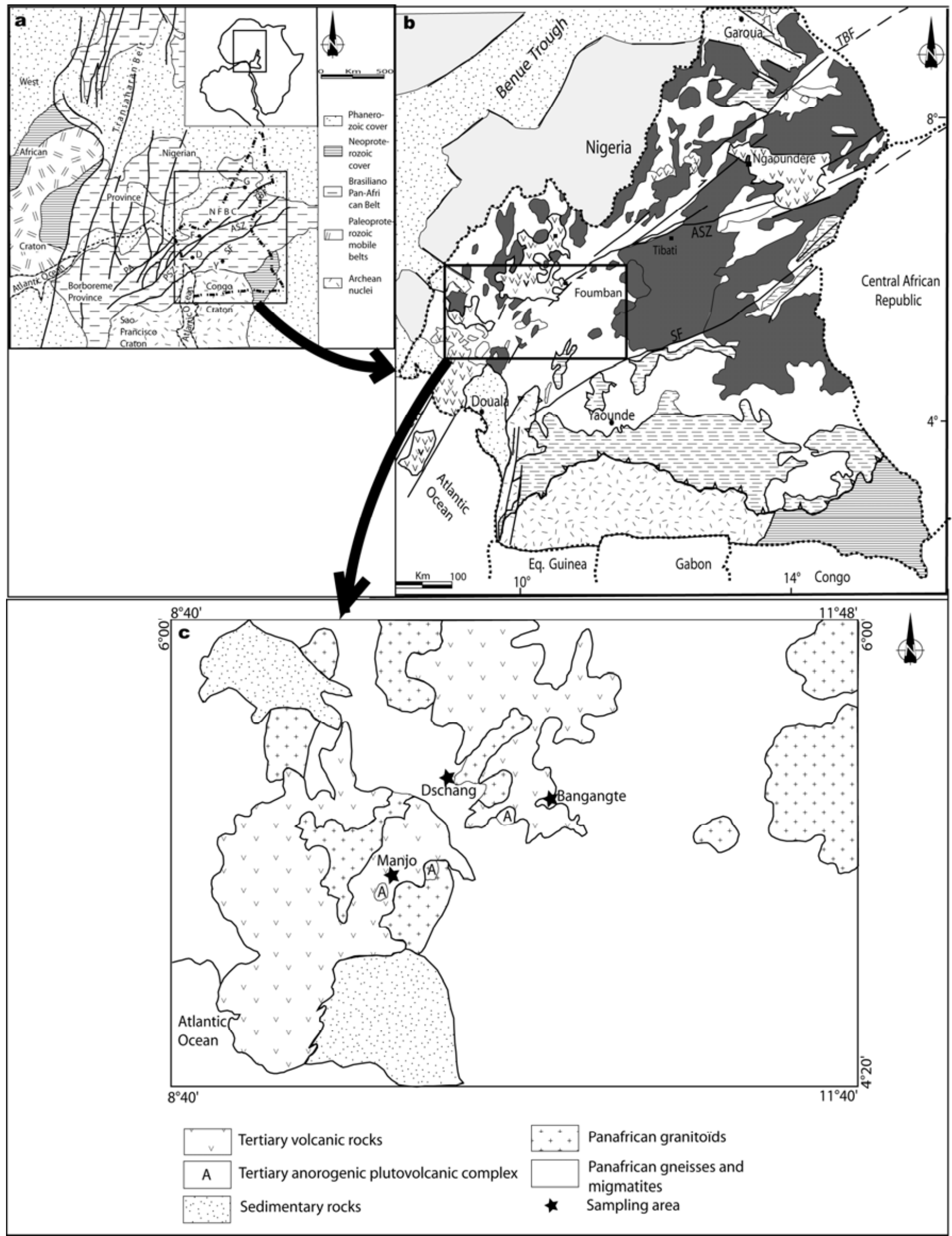

Fig. (1). (a) Position of Cameroon in West Gondwana assembly and (b) geology map of Cameroon (in [10]). (c) Geological sketch map and samples location. 
and hypersthenes are found in some cases. Granitoids as well as gneissic rocks share common geochemical characters: I-type, high-K calcalkaline compositions.

Geochemical data on mafic dykes in the corridor of the Cameroon Volcanic Line exists only for the Mt. Cameroun area where they show lamprophyritic compositions (camptonites and monchiquites) and are clearly related to the alkaline magmatism of the Cameroon Volcanic Line [17]. Other occurrences are in the area of Benoue River in North Cameroon and the Adamawa plateau. In all these cases, they were inferred to be contemporaneous with and related to the nearby CVL alkali basalts [17-19]. The lamprophyres have high incompatible element contents and contain hydrous (kaersutite, biotite) and/or carbonate minerals and are interpreted to originate from a volatile-rich metasomatized lithospheric mantle [20]. In the Adamawa region, however, dykes are mainly doleritic [21]. Although undated, these dolerites with continental tholeiitic affinities are thought to be older since they were never found to crosscut the $51 \mathrm{Ma}$ plateau basalts of the early CVL units. Thus, they may not be related to the $\mathrm{CVZ}$ at all but rather may be linked to different magma sources and a distinct tectonic setting. Principal directions between $30^{\circ} \mathrm{E}$ and $70^{\circ} \mathrm{E}$ of these generally nearly vertical dykes are consistent with main characteristics of brittle deformation in the studied area [22] and indicate that a pre-Gondwana break-up (Panafrican) network of faults may have guided the ascent of these dykes to the surface.

\section{ANALYTICAL METHODS AND TECHNIQUES}

Twelve samples were selected for this study. Data are shown on Table 4.

Mineralogical and geochemical studies were carried out at the University of Gottingen. Clinopyroxenes, amphiboles and biotite were analysed by electron probe micro-analyzer (EPMA) at the University of Gottingen using a JEOL X8900 electron microprobe equipped with a wavelength dispersive analytical system. Operating conditions were $15 \mathrm{kV}$ and $12 \mathrm{nA}$ using a focused beam at counting times of 10 seconds. ZAF-corrections were made using atomic number, absorption and fluorescence incorporated routine methods.

Major and trace elements were determined using a Philip-PW 1408 XRF spectrometer. Analyses were carried out on lithium borate glass fusion beads. Relative precision $(2 \Sigma)$ for repeated measurements of standards is generally better than $2 \%$ for the major oxides and better than $10 \%$ for trace elements. Rare Earth and trace elements were analysed by inductively coupled plasma mass spectrometry (ICP-MS) on a VG-Plasma Quad STE-ICP mass spectrometer. The samples were dissolved in a Teflon pressure bomb, using a 1:1 mixture of $\mathrm{HF}$ and $\mathrm{HClO}_{4}$ at $180^{\circ} \mathrm{C}$, and then taken up in an $\mathrm{HNO}_{3}$ solution with an In-Re international standard. After dissolution in $\mathrm{HF}-\mathrm{HClO}_{4}$, the samples were taken up in a mixture of $\mathrm{HNO}_{3}, 6 \mathrm{~N} \mathrm{HCl}$ and $\mathrm{Hf}$ and diluted. These solutions were measured within 24 hours after dilution to prevent absorption of HFSE. Isotope ratios for $\mathrm{Sr}$ and $\mathrm{Nd}$ were measured with a Finnigan MAT 262 RPQ II+ mass spectrometer at Göttingen. Whole-rock powders (ca. 100 $\mathrm{mg}$ ) were dissolved in $\mathrm{HF} / \mathrm{HNO}_{3}$. The $\mathrm{Sr}$ and $\mathrm{Nd}$-isotope ratios were corrected for mass fractionation to ${ }^{86} \mathrm{Sr} /{ }^{88} \mathrm{Sr}=$ 0.1194 and ${ }^{146} \mathrm{Nd} /{ }^{144} \mathrm{Nd}=0.7219$ and normalized to values for NBS987 (0.710245), and La Jolla (0.511847), respectively. Measured values of these standards over the last 3 years in Göttingen were $0.710239 \pm 0.000004$ for $\mathrm{Sr}$ and $0.511844 \pm 0.000003$ for $\mathrm{Nd}$. External errors $(2 \mathrm{r}$ ) are estimated at $\pm 0.0004 \%$ for $\mathrm{Sr}$ and $\mathrm{Nd}$ isotopes. Procedural blanks for $\mathrm{Sr}$ and $\mathrm{Nd}$ (261 and $135 \mathrm{pg}$ respectively) were negligible.

\section{FIELD CHARACTERISTICS AND PETROGRAPHIC DESCRIPTIONS}

Within the sampling area, dykes are irregularly distributed. Taking into account the intense weathering of rocks that characterizes the region, great care was taken to collect only relatively fresh samples from outcrops along highways at Bangangté and Dschang, and in a quarry near Manjo (Fig. 2). Basalt dykes in the studied area only intrude the Precambrian basement and never into Tertiary plateau basalts.

Rose and density diagrams for strike and dip of 12 dykes (Fig. 3) indicate major orientations directions between $30^{\circ} \mathrm{E}$ and $70 \mathrm{E}$ and near vertical dip; the two dykes oriented $\mathrm{N} 100^{\circ} \mathrm{E}$ and $\mathrm{N} 150^{\circ} \mathrm{E}$ are located in the Dschang area. Many dikes are intensely internally fractured with reflecting no systematic (and presumably rather local) stress patterns.

\section{Dschang Area}

Six dykes have been identified within the Precambrian host rock assemblage, along the escarpment west of the city of Dschang. Dyke emplacement occurred with development of numerous apophyses and intensebrittle fragmentation of the country rocks (Fig. 2d, e). Rocks show remarkable uniform subophitic texture (Fig. 4d) with large phenocrysts of olivine and plagioclases representing 25 vol. $\%$ of the rock. The groundmass is comprised of plagioclase, micrograins of olivine, augite and Fe-Ti-oxides. One dyke shows locally variations to a fluidal texture underlined by smaller laths of plagioclase. Both plagioclase and olivine phenocrysts are frequently altered.

\section{Manjo Area}

Three basalt dykes from a quarry at $5 \mathrm{~km}$ to the north of the city of Manjo show thicknesses varying between 0.3 and $0.65 \mathrm{~m}$ (Fig. 2c). Dykes are homogeneous with intragranular to interstitial, subophitic texture (Fig. 4c, d): Primary minerals include augite, hypersthene, plagioclases, minor biotite, and rare zircons. Secondary minerals are amphibole, biotite, and calcite. Plagioclase occurs as large laths varying in length between 0.5 and $1.5 \mathrm{~mm}$. Saussuritization of plagioclase is frequent with fomation of epidote, sericite and often calcite. Augite phenocrysts are frequently replaced by secondary fibrous green hornblende. Small flakes of biotite can form from some pyroxenes, but biotite is also found as small plates with diameters below $0.1 \mathrm{~mm}$.

\section{Bangangté Area}

In the Bangangté area, three dykes were studied: two basaltic dykes located $10 \mathrm{~km}$ [11] to the north-west of the city of Bangangté (Bangwa) and one dyke at $25 \mathrm{~km}$ to the southeast of the city (Maham). Thicknesses of the dykes vary from $1.20 \mathrm{~m}$ in the Maham area (Fig. 2a) to $20 \mathrm{~cm}$ in the Bangwa area (Fig. 2b). Basaltic dykes at Bangwa are porphyritic, with olivine and plagioclase phenocrysts in a 

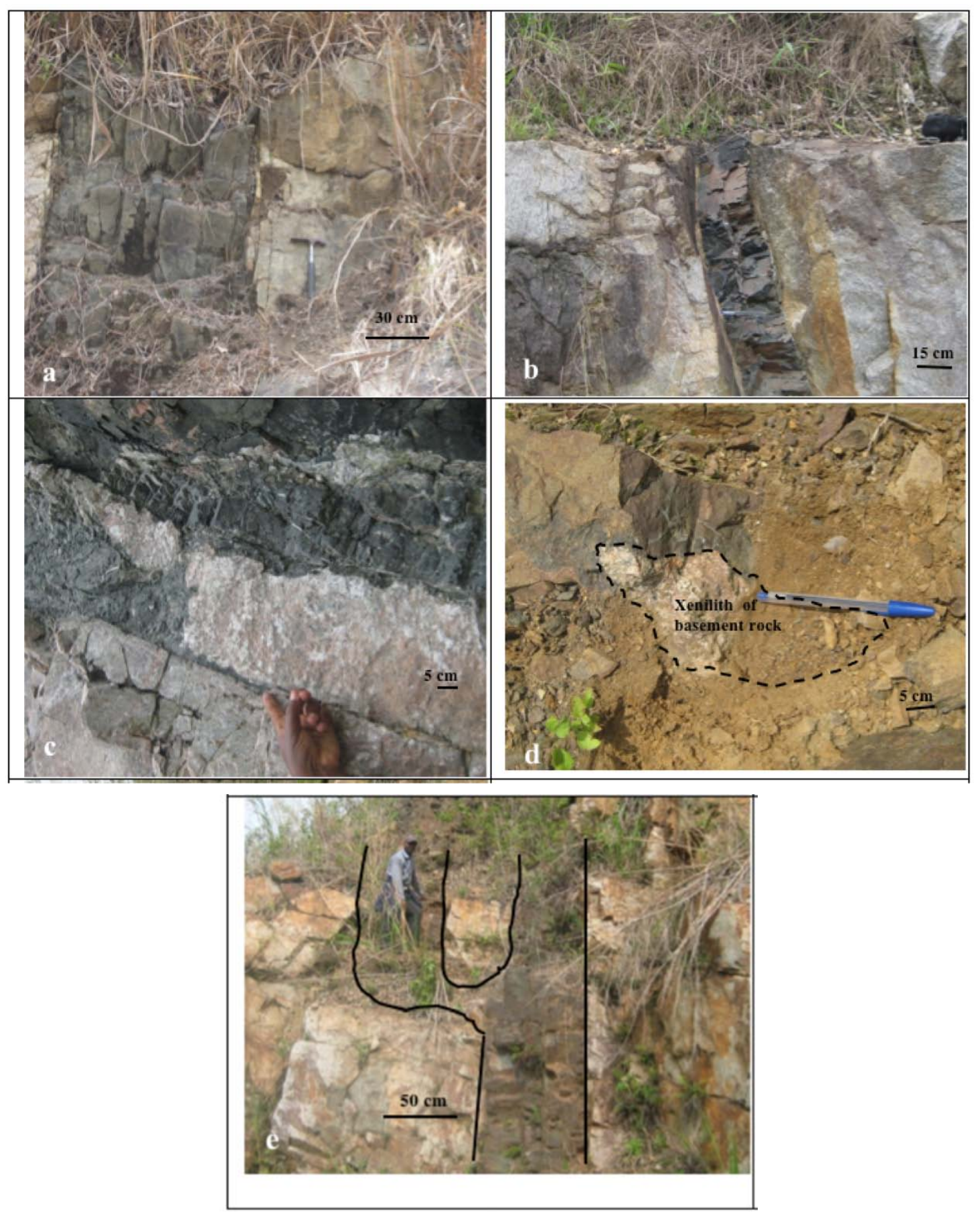

Fig. (2). Front view of basalt dykes. Intense fracturation and large variations of dykes sizes in the Bangangate area (a, b); dike in contact with country rock at Manjo (c). Note fragmantation and thin balastic injection into fissures of the host rock. Blocks of basement included as fragments and xenoliths in Dschang dykes $(\mathbf{d}, \mathbf{e})$.

matrix made up of plagioclase, olivine, augite, and chromite microlites (Fig. 4b). Xenoliths minerals (quartz, amphiboles) of basement rocks are frequent at Bangwa (Fig. 4c). In the Maham area the porphyritic dykes depict a clear fluidal texture at the contact with the gneissic basement and glassy selvages at the sharp contacts with the country rocks (Fig. 4a).

\section{MINERAL CHEMISTRY}

Clinopyroxenes, and biotite, amphiboles, plagioclases were analysed by electron microprobe. Clinopyroxene phenocrysts are relatively abundant compared to olivines which are mostly affected by alteration. Data are shown in Table 1. Clinopyroxenes are diopside to augite in composition (Fig. 4d, 5) according to the classification of [23] with compositions in the range $\mathrm{Wo}_{49-43} \mathrm{Ens}_{32-43} \mathrm{Fs}_{12-24}$. Clinopyroxenes in the Bangangte and Dschang areas are augites and diopside in the Manjo area. Based on the amount of $\mathrm{Ti}$ and $\mathrm{Ca}$, clinopyroxenes can be distinguished and classified as titaniferous calcic clinopyroxene (Bangangté and Dschang area) and weakly non-titaniferous calcic- 


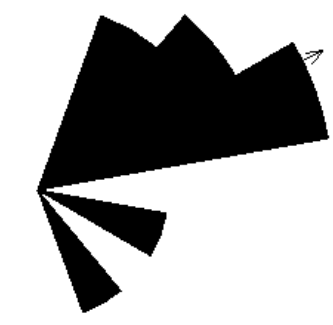

Total data: 12

Largest frequency $42 \%$

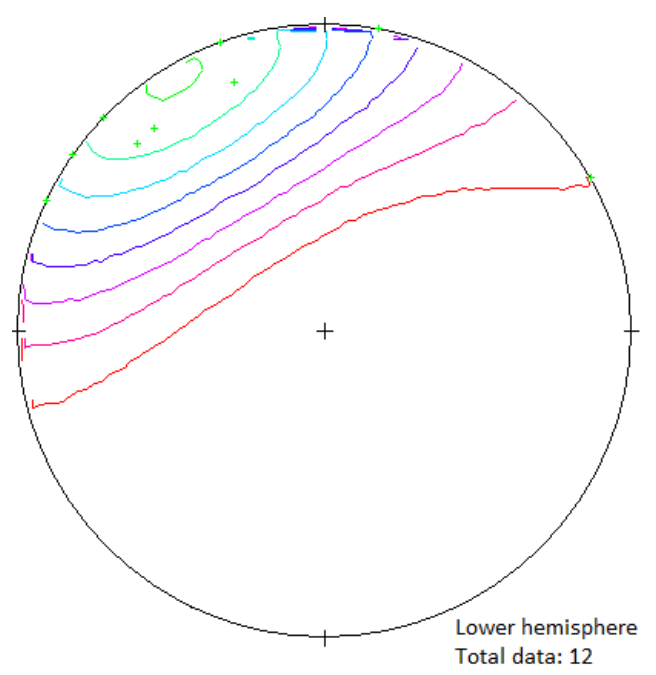

Fig. (3). Rose diagram and poles of dykes. Most dykes are oriented between $\mathrm{N} 30$ and $\mathrm{N} 70^{\circ} \mathrm{E}$ with near to vertical dips.
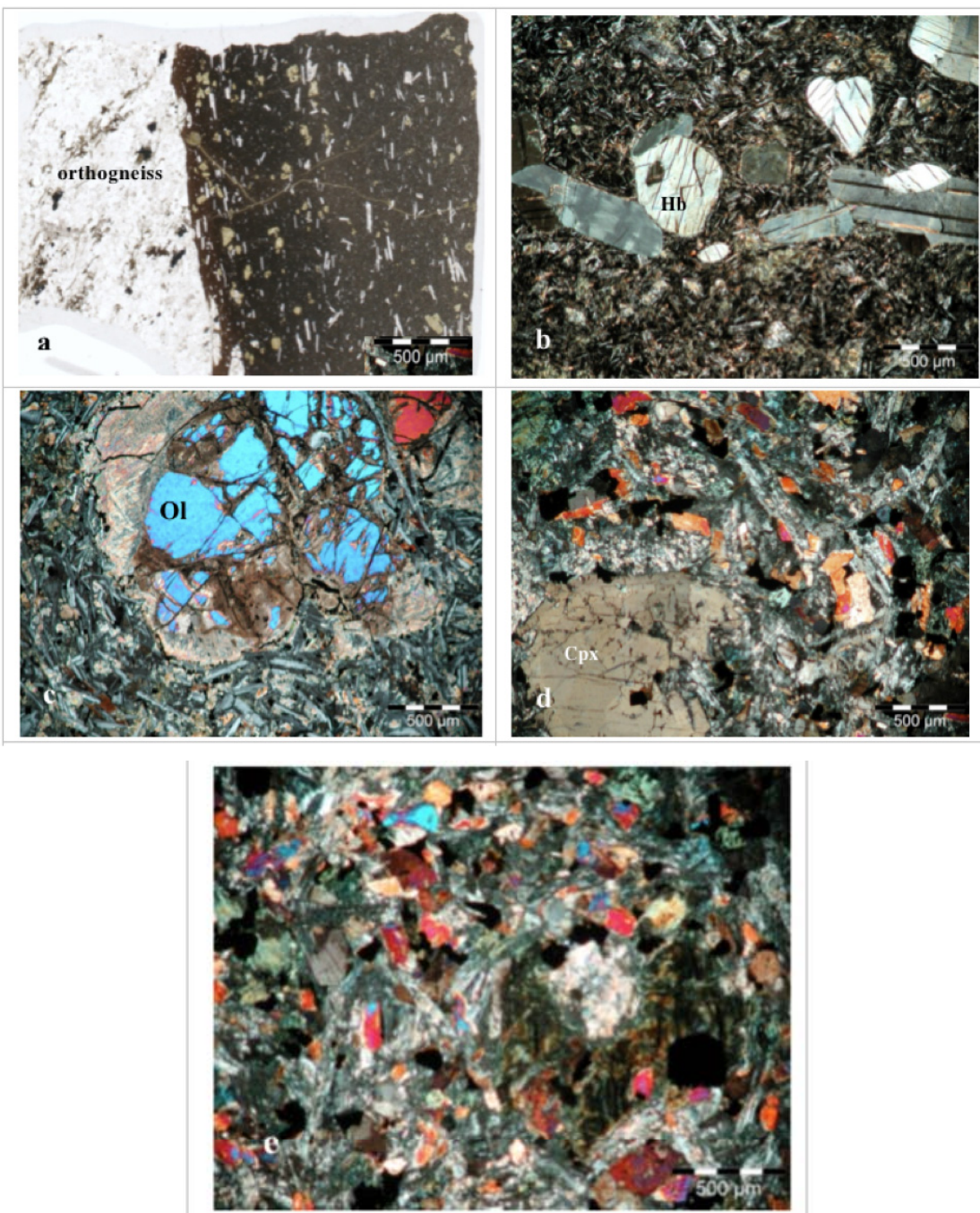

Fig. (4). Photomicrographs showing main textural characteristics of the dykes (a) Fluidiality in the microlitic texture of near the contact with bed rock (orthogeneiss) of dyke a on Fig. (2). Sharp contacts indicate that the dyke was put in place along a preeexisting fracture. (b) xenoliths (quartz, green hornblende) of the basement rocks in dyke 2-B. (c) microlitic porphyritic textures and intense alteration of olivines in a dykes of the Dschang area. (d, e) microlitic prophyritic textures and hydrous minerals (green hornblende, biotites) in dykes of the Manjo area. OI, Olivine ; Cpx, Clinopyroxene ; Hb, Green Hornblende. 
Table 1. Selected Electron Microprobe Analyses of Clinopyroxenes

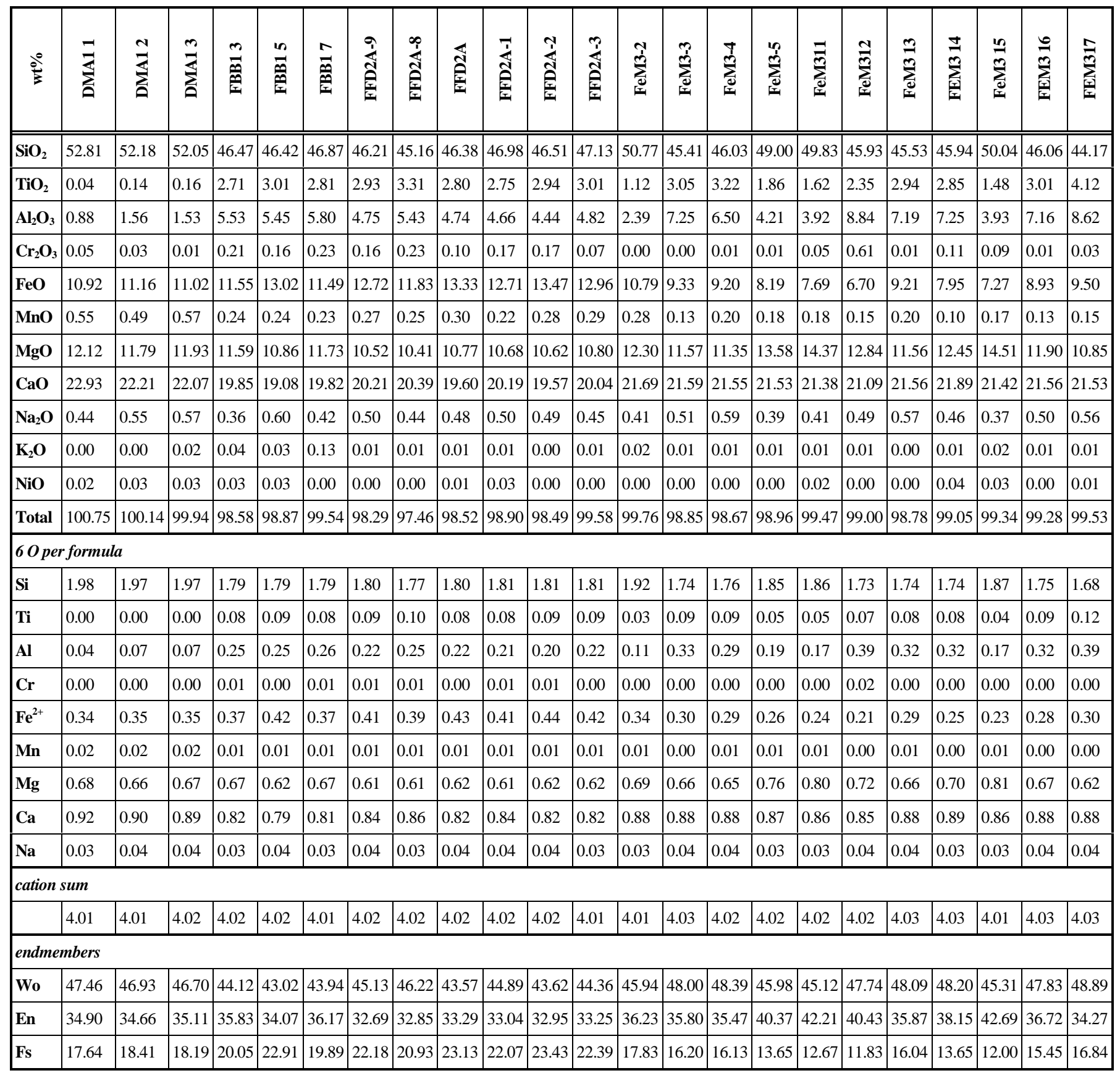

clinopyroxene (Manjo area). Amphiboles and biotites clearly secondary alteration products (Fig. 4e). Biotite crystals are euhedral $(<1 \mathrm{~mm})$ and exist only in the dykes of the Manjo area. They are close to Annite composition. Amphiboles occur only in the Manjo area and are of Tschermakitic type.

When compared to phenocryst data from Cameroon Line volcanics and related dykes, augites are closer to those of the Bana transitional tholeiites with compositions in the range $\mathrm{Wo}_{47-36} \mathrm{Ens}_{35-40} \mathrm{Fs}_{15-25}$ (Kuepouo et al., 2006) than representatives of basalt dykes in North Cameroon with $\mathrm{Wo}_{38-26} \mathrm{Ens}_{42-54} \mathrm{Fs}_{23-52}$ (Ngounouno et al., 2001).

\section{WHOLE ROCK GEOCHEMISTRY}

The dykes have restricted $\mathrm{SiO}_{2}$ content from 46.6 to 50.9 wt.\% with lowest values in the Manjo area, $\mathrm{MgO}$ spanning 7.18-9.38 wt.\% (Table 2). The magnesium number $\mathrm{Mg \#}$ $\left(=\mathrm{Mg} / \mathrm{Mg}+\mathrm{Fe}^{2+}\right)$, calculated on the basis of $\mathrm{Fe}_{2} \mathrm{O}_{3} / \mathrm{FeO}=0.10$, varies from 53 to $59 . \mathrm{K}_{2} \mathrm{O}+\mathrm{Na}_{2} \mathrm{O}$ is less than $4.4 \mathrm{wt} \%$. $\mathrm{Na}_{2} \mathrm{O} / \mathrm{K}_{2} \mathrm{O}$ ratio varies from 1.38 to 5.08 , with the highest value coming from the Dschang area, which partly may be due to alteration effects. $\mathrm{TiO}_{2}$ contents are between 1.36 and $2.62 \mathrm{wt} . \%$, with highest values (up to $2.62 \mathrm{wt} . \%$ ) found in the Manjo area. Highest $\mathrm{Al}_{2} \mathrm{O}_{3}$ values (17.04 wt.\%) are also 


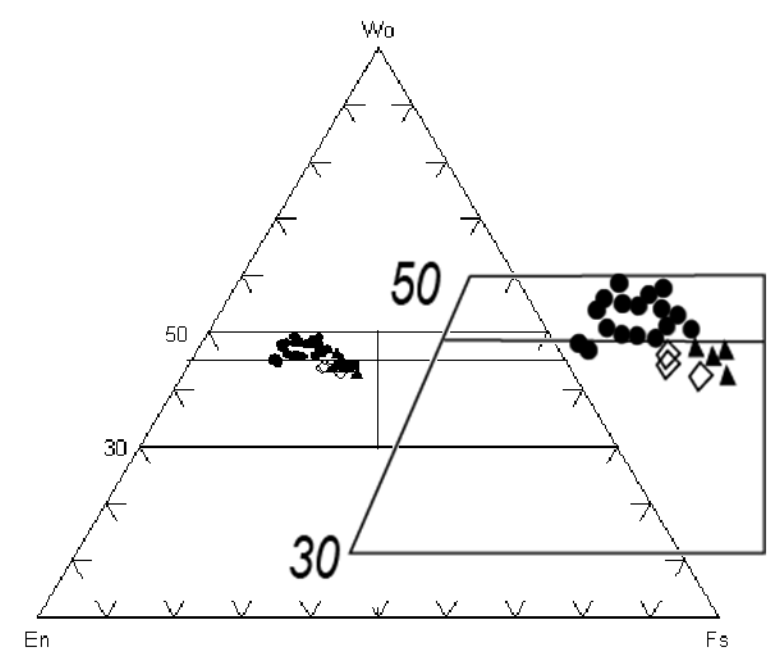

Fig. (5). Clinopyroxene compositions. Symbols: diamonds (Bangangte). triangles (Dschang). circles (Manjo). Data span the boundary between Diopside and Augite pyroxenes in Bangangte and Dschang areas are augites while pyroxenes in the Manjo area are diopside.

found in the Manjo area. Following the classifications of [24], and [25], all rocks are silica over-saturated subalkaline basalts (Fig. 6), with the exception of one dyke (FEM3) from the Manjo quarry which contains 7.5 wt.\% of olivine, Variation diagrams for major elements show only small compositional ranges (Fig. 7).

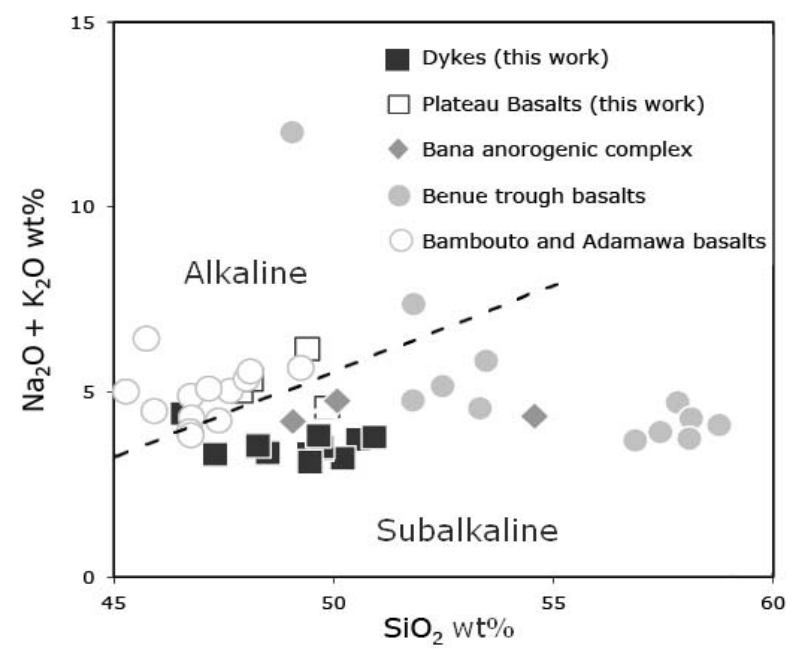

Fig. (6). Total alkali-Silica classification [24]. Dashed line delineates the boundary between alkaline and subalkaline basaltic series after [25]. Data source: Bana anorogenic complex [1]; Bambouto and Adamawa basalts [2]; Benue Through basalts [3].

Ratios of immobile incompatible elements (Fig. 8) should be largely independent of the degree of magmatic differentiation and also from secondary alteration effects and thus - if different, should indicate different magma sources.
Ratios such as $\mathrm{Sm} / \mathrm{Nd}, \mathrm{Zr} / \mathrm{Nb}, \mathrm{Ba} / \mathrm{Th}, \mathrm{Th} / \mathrm{La}, \mathrm{Ba} / \mathrm{La}$ and $\mathrm{Ba} / \mathrm{Nb}, \mathrm{K} / \mathrm{Nb}$ and $\mathrm{REE}$ patterns (Table 3, Figs. 9, 10) indicate that the dykes in the Bangangté and Dschang areas are similar, but slightly different from dykes in the Manjo area. Trace element patterns (Fig. 9) with concentrations normalized to chondrites compositions of [26] indicate relatively uniform enrichment in trace and rare earth elements, strong negative anomalies in Th and $\mathrm{U}$, slightly positive anomalies in $\mathrm{Nb}, \mathrm{La}$ and $\mathrm{Y}$. In order to evaluate our data with possibly equivalent mafic volcanic rocks from the early stage of Cameroon Line magmatism in the area, we compared our trace element patterns with those of the Tertiary basalts from the Cameroon Volcanic Line. A comparison between the dykes and the basaltic rocks of the Cameroon Volcanic Line (see Fig. 9a, b), shows that trace element patterns and abundances are quite distinct: Large Ionic Lithophile Elements and Light Rare Earth Elements are lower in the basalt dykes as shown on Fig. (8). Further comparison is made with basalt rocks from the Benue Trough in Nigeria [3], which - as we will discuss below bear many similarities to dyke rocks in Cameroon (Fig. 8).

Within the southern part of the Cameroon Volcanic Line, two dykes of basaltic affinity (camptonites) were described at Mount Cameroon (150 km to the SW of Manjo dykes area) by [17] that show some petrographic similarities with dykes of the Manjo area, i.e. the presence of minor amphiboles and biotites. However, major differences in their major and trace element geochemistry suggests that they are not related: The $\mathrm{K}_{2} \mathrm{O} / \mathrm{Na}_{2} \mathrm{O}$ ratio of the Manjo dykes studied here are between 3 and $4 \mathrm{wt} \%$ while at Mt Cameroon these values are much higher (4.64 and $8.33 \mathrm{wt} \%)$. Incompatible trace elements patterns show positive $\mathrm{K}$ anomalies and negative anomalies for Th, $\mathrm{U}$ for the Manjo dykes which are not observed for the Mt Cameroon dykes. The isotopic compositions are also distinct and the Mount Cameroon dikes with a K-Ar age of $1.46+-0.15 \mathrm{M}$ are also much younger [17]. The Mount Cameroon camptonites are thought to represent the least differentiated basalts of the Cameroon Volcanic Line. Thus, in spite of the petrogrphic similarity (i.e. the presence of amphiboles and biotites) the dykes of Manjo and Mount Cameroon areas are distinct in age, composition, magma source and thus also in their tectonic setting.

$\mathrm{Sr}$ and $\mathrm{Nd}$ isotope data where obtained on a representative set of dyke samples. These were selected on the basis of their range in $\mathrm{Sm} / \mathrm{Nd}$ and $\mathrm{Rb} / \mathrm{Sr}$ ratios. Since no (reliable) chronological data exist on the dike rocks, calculation of initial isotope ratios is poorly constrained. We used an age of $150 \mathrm{Ma}$ for the calculations for initial values based on the youngest K-Ar ages of [6] (Table 4). Notwithstanding the poorly constrained age, two main conclusions can be drawn from the data in Fig. (9): (a) the isotope composition of our dyke are clearly different from the CVL basalts, and (b) the basaltic dykes were derived from a slightly enriched mantle source similar to those documented for basalts related to the opening of the southern Atlantic Ocean (e.g. Nigerian Jurassic dykes and Parana Basalts (Fig. 11). 

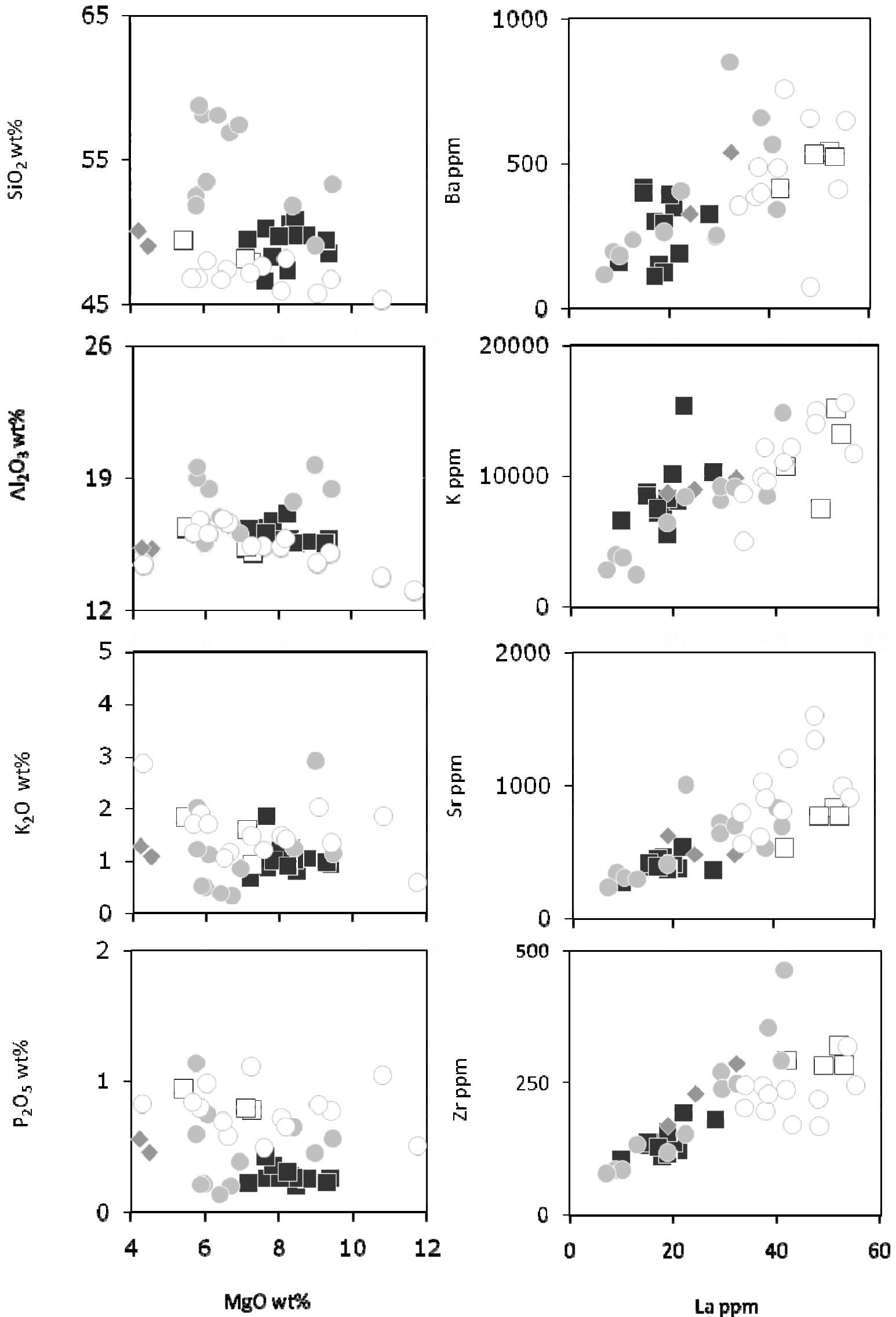

Fig. (7). Variation diagrams of major elements versus $\mathrm{MgO}$ and and trace elements versus La. Studied basaltic dykes mostly plot closer to the Benue Through samples [3]. Symbols as in Fig. (6). 


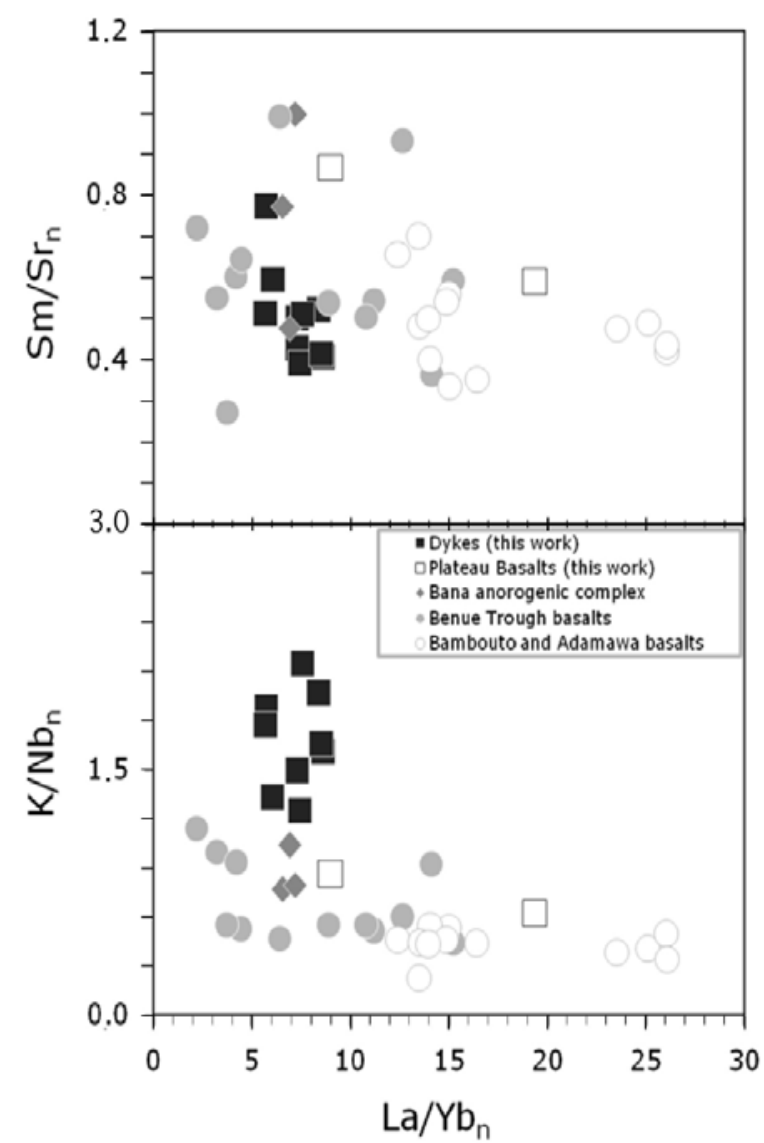

Fig. (8). $\mathrm{Sm} / \mathrm{Sr}_{\mathrm{n}}$ against $\mathrm{La} / \mathrm{Yb}_{\mathrm{n}}$ and $\mathrm{K} / \mathrm{Nb}_{\mathrm{n}}$ against $\mathrm{La} / \mathrm{Yb}_{\mathrm{n}}$ showing that basalt dykes samples plot closer to basalts from the Benue Through and are distinct from alkaline basalts of the Cameroon Volcanic Line represented here by the plateau basalts and the Bambouto and Adamawa basalts.

\section{DISCUSSION}

Major orientations of 10 of the 12 studied dykes the dykes fall in the interval $\mathrm{N} 30^{\circ} \mathrm{E}$ to $70^{\circ} \mathrm{E}$ which corresponds to the major direction of the Tertiary CVL $\left(\mathrm{N} 30^{\circ} \mathrm{E}\right)$ and the Precambrian Adamawa Shear Zone $\left(70^{\circ} \mathrm{E}\right)$. These two major directions of the dykes fit into a Riedel fracture model [27] with E-W or N-S as the two sets of conjugate shear directions corresponding in a simple shear model to a direction of compression around $40^{\circ}$ and extension at ca. $100^{\circ}$. Since this direction is roughly parallel to the African coast in the region and may thus be related to the opening of the Atlantic Ocean.

Geochemically, dykes studied here represent closely associated and relatively evolved magmas $(53<\mathrm{Mg \#}<59)$. Primitive lavas directly derived from the upper mantle $(\mathrm{Mg} \#$ of 68-72; [28]) are not observed. Because of their low concentrations in LILE, HFSE and Y compared to those of the Cameroon Volcanic Line (e.g. Plateau basalts, see above), these dykes are similar to tholeiitic dykes in North Cameroon [18], which were thought by [20] to also be unrelated the Cameroon Volcanic Line. Trace element characteristics as shown here much more closely resemble those from tholeiites of the Benue through in Nigeria [17].
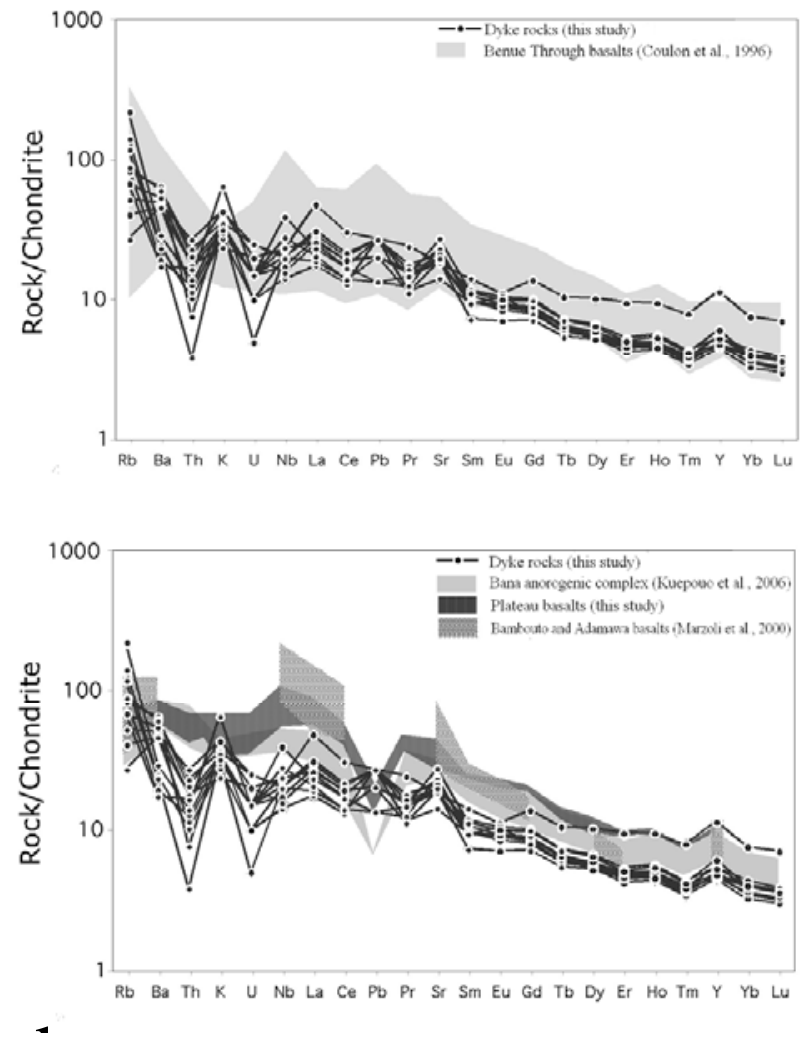

Fig. (9). Spider diagram for incompatible trace elements using the chondrite normalizing values of [26]. Basaltic dykes overlap the Benue Through basalts (a) and are less enriched in incompatible trace elements than representatives of the Cameroon Volcanic Line (b).

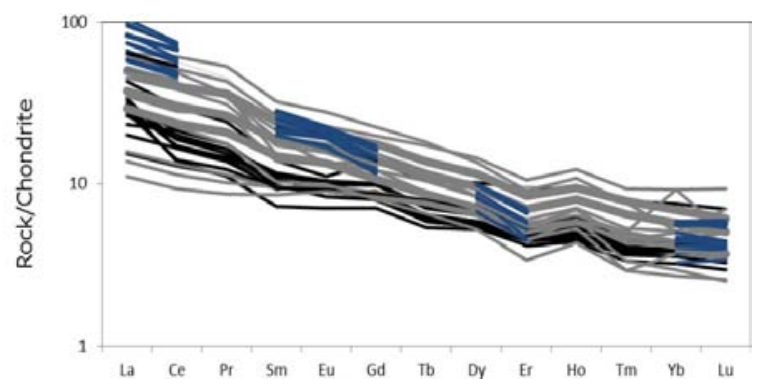

Fig. (10). Chondrite-normalized rare earth element (REE) diagram for dykes samples (black lines) along with fields for Benue through basalts [3] (dark grey lines ), Bana anorogenic complex [1] (tick dark grey) and Bambouto [2] (colored lines) showing moderate degrees of REE enrichment. Chondrite normalizing values of [26].

In west-central Africa, magmatism associated with past continental rifting has been dominantly tholeiitic [29-31]. The basaltic dykes share many geochemical features with these basaltic rocks related to the opening of the Atlantic. CIPW compositions are quartz- and hypersthene-normative for all but one sample; a samples (FEM3) of the Manjo area which is olivine normative. This is consistent with a tholeiitic nature, even if modal hypersthenes (most consistent with tholeiitic affinity) was not observed in dykes of the Bangangte and Dschang areas. Basalts having similar characteristics are described in the Tertiary CVL volcanism 
Table 2. XRF Whole-Rocks Analyses of Basalt Dykes from Bangangte. Dschang. Manjo (FEM1.FEM2.FEM3) and Plateau Basalts from the Bangangte Area. Major Elements are Normalised to 100 LOI-Free. LOI (Loss on Ignition) is Given to Assess the Degree of Alteration

\begin{tabular}{|c|c|c|c|c|c|c|c|c|c|c|c|c|c|c|c|c|}
\hline & \multicolumn{3}{|c|}{ Bangangte } & \multicolumn{6}{|c|}{ Dschang } & \multicolumn{3}{|c|}{ Manjo } & \multicolumn{4}{|c|}{ Plateau basalts Bangangte } \\
\hline $\mathrm{TiO}_{2}$ & 1.68 & 1.56 & 1.54 & 1.51 & 1.91 & 1.48 & 1.38 & 1.51 & 1.36 & 2.05 & 2.16 & 2.62 & 2.74 & 2.71 & 3.99 & 2.73 \\
\hline $\mathbf{A l}_{2} \mathbf{O}_{3}$ & 15.82 & 15.51 & 16.32 & 15.57 & 15.76 & 15.63 & 16.25 & 15.73 & 15.52 & 16.68 & 17.04 & 16.03 & 16.35 & 15.33 & 15.63 & 15.04 \\
\hline MgO & 8.31 & 8.47 & 7.68 & 8.41 & 9.38 & 8.77 & 7.18 & 8.03 & 9.29 & 7.85 & 8.24 & 7.65 & 0.17 & 0.21 & 0.19 & 0.21 \\
\hline $\mathrm{CaO}$ & 8.93 & 8.64 & 10.83 & 9.44 & 9.26 & 8.24 & 10.81 & 9.48 & 9.24 & 9.64 & 9.82 & 10.49 & 7.39 & 8.40 & 7.52 & 8.67 \\
\hline $\mathrm{Na}_{2} \mathrm{O}$ & 2.47 & 2.99 & 2.35 & 2.49 & 2.43 & 2.4 & 2.43 & 2.6 & 2.37 & 2.56 & 2.41 & 2.56 & 4.33 & 3.74 & 3.22 & 4.12 \\
\hline $\mathbf{K}_{2} \mathbf{O}$ & 1.24 & 0.79 & 0.86 & 1.02 & 0.92 & 1.05 & 0.67 & 1.22 & 0.97 & 0.99 & 0.9 & 1.85 & 1.83 & 1.59 & 1.35 & 0.91 \\
\hline Mg\# & 0.58 & 0.58 & 0.58 & 0.57 & 0.59 & 0.56 & 0.53 & 0.56 & 0.59 & 0.55 & 0.56 & 0.54 & 0.46 & 0.51 & 0.33 & 0.51 \\
\hline \multicolumn{17}{|c|}{$p p m(X R F)$} \\
\hline Ba & 323 & 160 & 300 & 399 & 152 & 416 & 298 & 391 & 349 & 125 & 114 & 189 & 539 & 525 & 413 & 530 \\
\hline $\mathbf{R b}$ & 31 & 84 & 16 & 53 & 70 & 49 & 24 & 53 & 40 & 52 & 40 & 131 & 41 & 38 & 25 & 37 \\
\hline Th & 2.1 & 0.8 & 0.9 & 1.8 & 0.3 & 0.6 & 1.4 & 1.6 & 1.4 & 1 & 1.3 & 1.1 & 5.1 & 5 & 3.2 & 4.5 \\
\hline $\mathrm{Sr}$ & 359 & 278 & 446 & 413 & 463 & 391 & 366 & 419 & 373 & 369 & 388 & 538 & 829 & 769 & 529 & 769 \\
\hline Nb & 15 & 9.2 & 13.1 & 13.1 & 13 & 12.9 & 10.2 & 12.9 & 11.2 & 18.1 & 15.4 & 25.4 & 66.9 & 68.2 & 34.4 & 67.8 \\
\hline $\mathbf{Z r}$ & 180 & 107 & 136 & 137 & 110 & 131 & 114 & 136 & 121 & 155 & 129 & 193 & 320 & 283 & 294 & 284 \\
\hline $\mathbf{Y}$ & 48.6 & 20.3 & 19.7 & 20.6 & 19.2 & 19.9 & 19.4 & 20.4 & 19.7 & 23.5 & 22.7 & 25.9 & 29.4 & 33.9 & 42.8 & 34 \\
\hline $\mathbf{Z n}$ & 103 & 103 & 88 & 95 & 94 & 92 & 89 & 94 & 92 & 87 & 89 & 85 & 1390 & 16 & 164 & 119 \\
\hline $\mathbf{U}$ & 0.4 & 0.2 & 0.1 & 0.3 & 0.5 & 0.2 & 0.3 & 0.4 & 0.5 & 0.3 & 0.3 & 0.3 & 1.3 & 1.0 & 1.2 & 0.7 \\
\hline \multicolumn{6}{|c|}{ REE ppm (ICPMS) } & $\mathrm{XRF}$ & & & & & & & & $\mathrm{XRF}$ & & $\mathrm{XRF}$ \\
\hline La & 30.7 & 11.28 & 18.84 & 19.92 & 12.18 & 15 & 15.84 & 19.81 & 17.4 & 16.48 & 14.88 & 21.85 & 52 & 53 & 42 & 49 \\
\hline $\mathrm{Ce}$ & 50.33 & 21.62 & 33.41 & 35.65 & 23.49 & 38 & 28.69 & 35.54 & 31.4 & 31.81 & 27.84 & 41.35 & 96 & 91 & 71 & 95 \\
\hline Pr & 6.1 & 2.87 & 4.13 & 4.49 & 3.12 & & 3.65 & 4.45 & 3.91 & 4.13 & 3.69 & 5.29 & 11.51 & & 8.7 & \\
\hline Nd & 26.1 & 14.04 & 17.92 & 19.48 & 15.06 & 19 & 16.06 & 19.31 & 17.22 & 18.88 & 17.28 & 23.46 & 48 & 46 & 39 & 47 \\
\hline Sm & 5.66 & 3.81 & 3.89 & 4.32 & 3.84 & 39 & 3.74 & 4.35 & 3.96 & 4.71 & 4.53 & 5.42 & 10.4 & 8.3 & 8.2 & 8.8 \\
\hline Eu & 1.7 & 1.4 & 1.39 & 1.42 & 1.37 & & 1.26 & 1.41 & 1.28 & 1.61 & 1.53 & 1.91 & 3.39 & & 3.07 & \\
\hline Gd & 7.43 & 4.85 & 4.51 & 4.7 & 4.47 & & 4.29 & 4.83 & 4.34 & 5.46 & 5.29 & 6.17 & 10.01 & & 10.85 & \\
\hline Tb & 1.03 & 0.62 & 0.58 & 0.62 & 0.59 & & 0.6 & 0.64 & 0.58 & 0.72 & 0.7 & 0.8 & 1.13 & & 1.36 & \\
\hline Dy & 6.87 & 3.72 & 3.66 & 3.93 & 3.59 & & 3.72 & 3.94 & 3.65 & 4.48 & 4.3 & 4.98 & 6.31 & & 8.16 & \\
\hline Ho & 1.4 & 0.68 & 0.68 & 0.74 & 0.65 & & 0.71 & 0.74 & 0.7 & 0.83 & 0.8 & 0.9 & 1.02 & & 1.47 & \\
\hline $\mathbf{E r}$ & 4.14 & 1.93 & 1.97 & 2.14 & 1.82 & & 2.07 & 2.15 & 2.01 & 2.32 & 2.2 & 2.54 & 2.79 & & 4.1 & \\
\hline $\mathbf{T m}$ & 0.53 & 0.24 & 0.25 & 0.27 & 0.23 & & 0.26 & 0.27 & 0.25 & 0.29 & 0.28 & 0.31 & 0.3 & & 0.51 & \\
\hline $\mathbf{Y b}$ & 3.31 & 1.5 & 1.58 & 1.79 & 1.42 & & 1.76 & 1.79 & 1.7 & 1.9 & 1.75 & 2.04 & 1.83 & & 3.17 & \\
\hline Lu & 0.47 & 0.21 & 0.22 & 0.25 & 0.2 & & 0.24 & 0.25 & 0.24 & 0.26 & 0.24 & 0.29 & 0.25 & & 0.44 & \\
\hline
\end{tabular}


Table 3. Trace Elements Ratios Compared with OIB End-Members. N-MORB. PM and Average Continental Crust from [32]

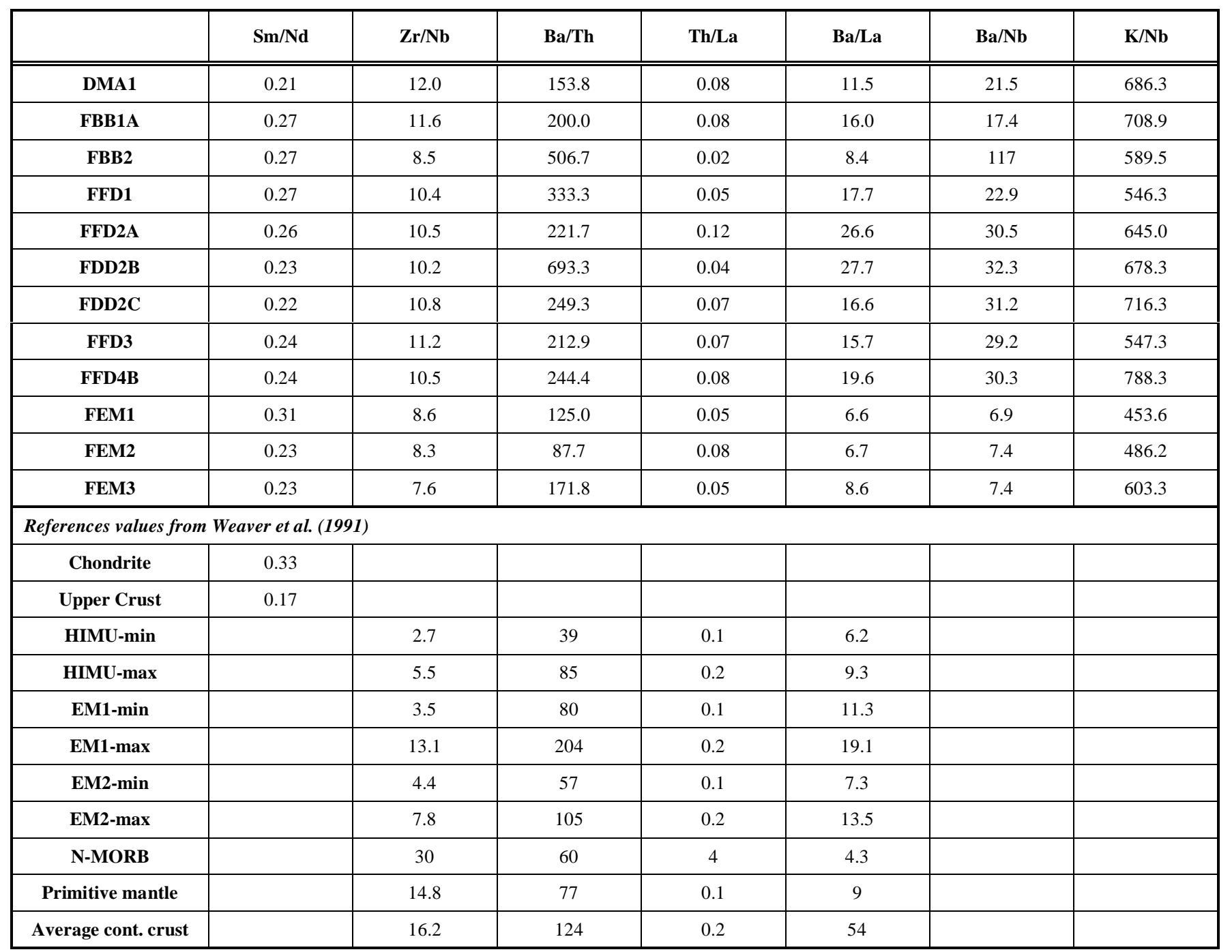

Table 4. Initial Ratios for ${ }^{87} \mathrm{Sr} /{ }^{86} \mathrm{Sr}$ and ${ }^{143} \mathrm{Nd} /{ }^{144} \mathrm{Nd}$ Calculated for $\mathrm{t}=150 \mathrm{Ma}$ (See Text for Further Explanation)

\begin{tabular}{|c|c|c|c|c|c|c|c|c|c|c|c|c|}
\hline Samples & Rb ppm & Sr ppm & ${ }^{87} \mathrm{Sr} /{ }^{86} \mathrm{Sr}$ & $2 \mathrm{SE}$ & ${ }^{87} \mathbf{R b} /{ }^{86} \mathrm{Sr}$ & $\left({ }^{87} \mathrm{Sr} /{ }^{86} \mathrm{Sr}\right)_{150 \mathrm{Ma}}$ & Sm ppm & Nd ppm & ${ }^{143} \mathbf{N d} /{ }^{144} \mathrm{Nd}$ & 2SE & ${ }^{147} \mathrm{Sm} /{ }^{144} \mathrm{Nd}$ & $\left({ }^{143} \mathrm{Nd} /{ }^{144} \mathrm{Nd}\right)_{150 \mathrm{Ma}}$ \\
\hline FFD2a & 53 & 413 & 0.706273 & 0.00001 & 0.3712 & 0.705481 & 4.9 & 19 & 0.512223 & 0.000006 & 0.2579 & 0.511970 \\
\hline FFD3 & 24 & 366 & 0.705379 & 0.000012 & 0.1897 & 0.704974 & 3.9 & 16 & 0.512245 & 0.000006 & 0.1484 & 0.512099 \\
\hline FFD4b & 53 & 419 & 0.706799 & 0.000012 & 0.3659 & 0.706018 & 4.6 & 19 & 0.512232 & 0.000008 & 0.1474 & 0.512087 \\
\hline
\end{tabular}

of the region in the Bana anorogenic complex [15], the widely distributed plateau basalts in the Bayangam [32] and Foumban [33] region. Thus, in terms of major elements and petrographic compositions alone, it is difficult to prove or disprove a genetic similarity between the dykes investigated in this study and the older Tertiary Volcanics of the Cameroon Volcanic Line.

Trace elements patterns and isotope ratios are more conclusive and clearly rule out similarities (and thus genetic relationships) between the studied dykes and the Cameroon Volcanic Line. Rather, these dyke rocks show trace element patterns from tholeiites of the southern part of the Benue through in Nigeria [3], which is located at the same latitudes as the dykes studied here. These basalts were thought to be of plume origin [3] and to have erupted during a period of crustal thinning (by $10 \mathrm{~km}$ or more) during the opening of the South Atlantic Ocean [34]. Their similarity with dyke rocks in Cameroon, the presumed synchronicity and the wide distribution of these related volcanic rocks suggest a much larger area of lithospheric thinning and mantle melting related to the opening of the south Atlantic bordering Central Africa. 


\section{CONCLUSION}

This work has documented olivine-bearing basaltic dykes of tholeiitic to transitional rift-related character over a large area in southern Cameroon. There are two main geodynamic events in the area to which these dykes potentially could be related: (a) the opening of the Central Atlantic, and; (b) the initial phase of building up of the Cameroon Volcanic Line. Trace element characteristics and $\mathrm{Sr}-$ and $\mathrm{Nd}$ isotope data clearly rule out a genetic relation to Cameroon Volcanic Line magma sources and rather document similarities to preTertiary volcanic rocks of the Benue Through in Nigeria. This igneous activity that occurred during the opening of the Equatorial Atlantic was apparently much more widely distributed. Further investigations of magma compositions and ages of dykes injection should thus bear important clues on the timing and process of Atlantic rifting.

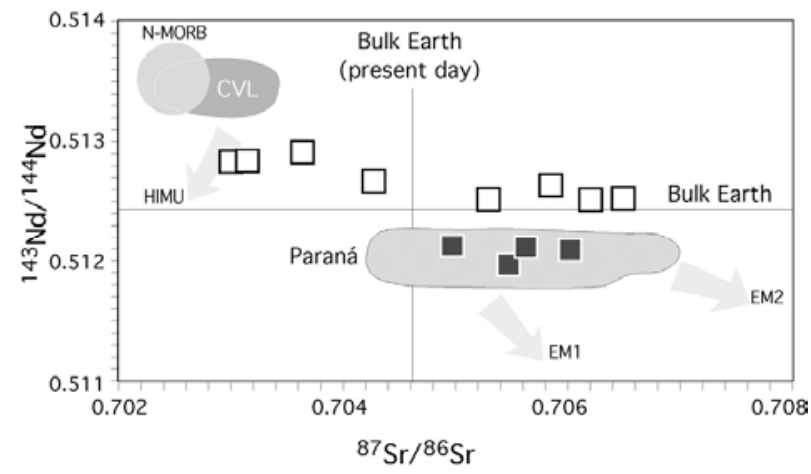

Fig. (11). ${ }^{143} \mathrm{Nd} /{ }^{144} \mathrm{Nd} v s{ }^{87} \mathrm{Sr} /{ }^{86} \mathrm{Sr}$ ratios for basalt dykes of the Dschang area at $150 \mathrm{Ma}$. CVL: Cameroon Volcanic Line. Fields for CVL and Parana are after [3]. Symbols: black squares. basalt dykes (this work); open squares. Benue through basalts [3].

\section{ACKNOWLEDGEMENTS}

This work was funded by the German Science Foundation (DFG project Wo362/37-1). G. Hartman, A. Kronz and K. Simon are appreciated for their analytical support.

\section{CONFLICT OF INTEREST}

The authors confirm that this article content has no conflict of interest.

\section{REFERENCES}

[1] Kuepouo G, Tchouankoue JP, Nagao T, Sato H. Transitional tholeiitic basalts in the Tertiary Bana volcano-plutonic complex, Cameroon Line. J Afr Earth Sci 2006: 45: 318-32.

[2] Marzoli A, Renne PR, Piccirillo EM, et al. The Cameroon Volcanic Line Revisited: Petrogenesis of continental basaltic magmas from lithospheric and asthenospheric mantle sources. J Petrol 2000; 41: 87-109.

[3] Coulon C, Vidal P, Dupuy C, Boudin P, et al. The Mesozoic to Early Cenozoic Magmatism of the Benue Through (Nigeria): Geochemical Evidence for the Involvement of the St. Helena Plume. J Petrol 1996; 37: 1341-58.

[4] Weeksteen G. Carte géologique de reconnaissance du territoire du Cameroun au 1/500000 et notice explicative, feuille Douala-Est. Dir. Mines et Géologie. Yaoundé-Cameroun: Imprimerie Nationale 1957.

[5] Dumort JC. Explanatory notes on the sheet Douala West. Reconnaissance geology map of Cameroon at scale 1/500000. Yaounde-Cameroon: National Printing House 1968.
Tchouankoue JP. Geochronology of the Precambrian basement of West-Cameroon: evidence of a major Paleoproterozoic/Neoproterozoic crustal boundary in Cameroon and its prolongation in North-East Brazil. Doctoral thesis. Cameroon: University of Yaounde I. 2005; p. 133.

[7] Van Schmus WR, Brito Neves BB, Hackspacher P, Babinski M. $\mathrm{U} / \mathrm{Pb}$ and $\mathrm{Sm} / \mathrm{Nd}$ geochronologic studies of the eastern Borbomera province, northeastern Brazil: initial conclusions. J South Am Earth Sci 1995; 8: 267-88.

[8] Toteu SF, Van Schmus WR, Penaye J, Michard A. New U-Pb and $\mathrm{Sm}-\mathrm{Nd}$ data from north-central Cameroon and its bearing on the pre-Pan African history of central Africa. Precambrian Res 2001; 108: 45-73.

[9] Brito Neves BB, Van Schmus WR, Fetter A. North-western AfricaNorth- eastern Brazil major tectonic links and correlation problems. J Afr Earth Sci 2002; 34: 275-8.

[10] Njiekak G, Dorr W, Tchouankoue JP. U-Pb zircon and microfabric data of (Meta) granitoids of Western Cameroon: Constraints on the timing of pluton emplacement and deformation in the Pan-African belt of Central Africa. Lithos 2008; 102: 460-77.

[11] Tchouankoue JP. The Bangangte syenite: A Pan-African complex with intermediate characters: petrology and geochemistry. Doctorate of Third Cycle thesis. Cameroon: University of Yaounde 1992; p.160.

[12] Kwekam M. The Pan-African pluton of Fomopea (West Cameroon): Structural Framework-Petrology-Geochemistry-geodynamic interpretation. Doctorate of Third Cycle Thesis. Cameroon: University of Yaounde 1993; p. 154

[13] Tchouankoue JP, Ghogomu RT, Tchoua FM. Comparative study of two plutons within atectonic granitoids in Cameroon. Ann Fac Sci Yaounde 1994; 3: 166-75.

[14] Tagne-Kamga G. The Ngondo Panafrican plutonic complex (West Cameroon): petrogenesis and structure. Doctorate thesis. France: University of Franche-Comte 1994; p. 224.

[15] Talla, V. The Pan-African granite of Batie (West Cameroon): petrology, structure, geochemistry. Doctorate of Third Cycle Thesis. Cameroon: University of Yaounde 1995; p.144.

[16] Nguiessi TC. The calc-alkaline complex of Bandja linked to the Pan-African mobile belt of West Cameroon. Doctorate Thesis. Cameroon: University of Nancy I 1995; p. 240.

[17] Ngounouno L, Déruelle B, Montigny R, Demaiffe D. Les camptonites du mont Cameroun, Afrique. C R Géosci 2006; 338: $537-44$.

[18] Ngounouno I, Deruelle B, Giraud R, Vicat JP. Magmatismes tholeiitique et alcalin des demi-grabens cretaces de Mayo OuloLere et de Babouri-Figuil (Nord du Cameroun-Sud du Tchad) en domaine d'extension continentale. C R Acad Sci 2001; 333(1): 201-7.

[19] Ngounouno I, Déruelle B, Demaiffe D, Montigny R. Petrology of the Cenozoic volcanism in the Upper Benue valley, northern Cameroon (Central Africa). Contrib Mineral Petrol 2003; 145(1): 87-106.

[20] Deruelle B, Ngounouno I, Demaiffe D. The Cameroon Hot Line (CHL): A unique example of active alkaline intraplate structure in both oceanic and continental lithospheres. C R Géosci 2007; 339: 589-600.

[21] Vicat JP, Ngounouno I, Pouclet A. Existence de dykes doléritiques anciens à composition de tholeiites continentales au sein de la province alcaline de la Ligne du Cameroun. Implications sur le contexte géodynamique. C R Acad Sci Paris 2001; 332: 243-9.

[22] Njiekak G, Zulauf G, Tchouankoue JP. Brittle deformation of the West Cameroon Highlands (Central part of the Cameroon Line). Zentralbl Geol Blaontol Tiel 2003; 2002: 243-65.

[23] Morimoto N, Fabries J, Ferguson IV, et al. Nomenclature of pyroxenes. Am Mineral 1988; 73: 1123-33.

[24] Le Bas MJ, Le Maitre RW, Streckeisen A, Zanettin B. A chemical classification of volcanic rocks based on the total alkali-silica diagram. J Petrol 1986; 27: 745-50.

[25] Irvine TN, Baragar WRA. A guide to the chemical classification of the common rocks. Can J Earth Sci 1971; 8: 523-48.

[26] McDonough WF, Sun SS. 1995. The composition of the Earth Chem Geol 1915; 120: 223-54.

[27] Moreau C, Regnoult JM, Deruelle B, Roineau B. A new tectonic model for the Cameroon line, central Africa. Tectonophysics 1987; $141: 317-34$ 
[28] Green DH. Compositions of basaltic magmas as indicators of conditions of origin: application to oceanic volcanism. Phil Trans Roy Soc Lond A 1971; 268: 707-25.

[29] Sebai A, Zumbo V, Ferand G, et al. ${ }^{40} \mathrm{Ar} /{ }^{39} \mathrm{Ar}$ dating of alkaline and tholeiitic magmatism of Saudi Arabia related to the early Red Sea Rifting. Earth Planet Sci Lett 1991; 104: 473-87.

[30] Fiechtner H, Friedrichsen H, Hammerschmidt K. Geochemistry and geochronology of early Mesozoic tholeiites from central Morocco. Geol Rundsch 1992; 81: 15-62.

[31] Harry DL, Sawyer DS. Basaltic magmatism, mantle plumes and the mechanics of rifting: the Parana flood basalt province of South America. Geology 1992; 20: 207-10.
[32] Fosso J, Menard JJ, Bardinzeff JM, Wandji P, Tchoua FM, Bellon $\mathrm{H}$. Les laves du mont Bangou: une première manifestation volcanique Eocène à affinité transitionnelle de la Ligne de Cameroun. C R Geosci 2005; 337: 315-25.

[33] Moundi A, Menard JJ, Reusser E, Tchoua FM, Dietrich V. Discovery of transitional basalts in th continental sector of the Cameroon Line ( Mbam massif , West-Cameroon). C R Acad Sci 1996; 32 (IIa): 831-7.

[34] Tokam KAP, Tabod TC, Nyblade AA, Julia J, Wins DA. Structure of the crust beneath Cameron, West Africa, from the joint inversion of Raleigh waves group velocities and receiver functions. Geophys J Int 2010; 183:1061-76.

(C) Tchouankoue et al.; Licensee Bentham Open.

This is an open access article licensed under the terms of the Creative Commons Attribution Non-Commercial License (http://creativecommons.org/licenses/by$\mathrm{nc} / 3.0 /$ ) which permits unrestricted, non-commercial use, distribution and reproduction in any medium, provided the work is properly cited. 